\title{
Volksvertegenwoordiging in de participatieve democratie: u zaagt, wij paaien?
}

Thibaut Renson

The times they are a-changing. De representatieve democratie is in crisis. De meerderheid van de huidige generatie Europese jongeren vindt het niet langer essentieel om in een democratie te leven (Foa \& Mounk, 2016; World Values Survey, 2016). Dat er vandaag, zoals in dit nummer, steeds meer aandacht is voor de vraag hoe we onze democratie kunnen herinrichten en voor onderzoek naar vernieuwende democratische experimenten, hoeft niet te verbazen. Dit essay probeert hiertoe een bijdrage te leveren door in te zoomen op de rol van politieke vertegenwoordiging in het licht van de participatieve democratie. Concreet handelt dit stuk over de vraag op welke manier de keuze van volksvertegenwoordigers voor meer burgerinspraak inwerkt op de relatie tussen vertegenwoordiger en vertegenwoordigde. Vanuit theoretisch oogpunt houdt de voorkeur voor meer participatieve democratie in de invited space ${ }^{1}$ immers de keuze in voor een welbepaalde invulling van politieke vertegenwoordiging. In de praktijk lijken vertegenwoordigers hierbij hun relatie met de burger niet op die manier te benaderen. Dit essay wil aantonen dat zo'n praktijk niet onschuldig is. Meer nog, eerder dan een remedie is zo'n praktijk van vertegenwoordiging in de participatieve democratie een symptoom van de crisis van de representatieve democratie. Daarnaast wil dit essay aantonen dat de participatieve democratie wel de potentie heeft om de relatie tussen vertegenwoordiger en vertegenwoordigde een nieuwe dimensie te geven die bijzonder zinvol kan zijn in het licht van die crisis.

\section{Vertegenwoordiging: een historische tweestrijd met actuele relevantie}

De vraag naar de invulling van politieke vertegenwoordiging gaat naar het hart van de relatie tussen burger en overheid. Sinds de demografische ontwikkeling het niet langer mogelijk maakte om burgers steeds zelf op rechtstreekse wijze aan politiek te laten doen, woedt de vraag hoe volksvertegenwoordigers hun rol moeten invullen. Een van de twee klassieke invullingen is deze 
van de vertegenwoordiger als gedelegeerde. In het delegate-model worden politici verondersteld uit te voeren wat burgers vragen (Heywood, 1997). Het beleid wordt verondersteld het volk te dienen. Niemand is bijgevolg beter in staat dan het volk zelf om hierover de meest correcte inschatting te geven. Vertegenwoordigers handelen dus niet naar eigen goeddunken, maar worden belast met de uitvoering van het mandaat dat hun kiezers aan hen gegeven hebben.

Gewezen Nederlands minister van Binnenlandse Zaken wijlen Hans Dijkstal (2001) gaf met zijn 'jukebox-democratie' een creatieve benaming voor die historische benadering. Collega Herwig Reynaert (Reynaert et al., 2006) had het recenter over de 'dj-democratie'. Volgens het delegate-model is het 'u-vraagtwij draaien'-principe de garantie voor het beste feestje. ${ }^{2}$

Aan de andere kant van het theoretische spectrum heb je het trustee-model van vertegenwoordiging. Volgens dat model worden vertegenwoordigers aangeduid door de kiezer als hun vertrouwelingen, die verondersteld worden te handelen naar eigen goeddunken (Elster, 1999). Ze zijn het aan hun kiezers verplicht om autonoom te handelen naar wat zij denken dat het beste is voor de samenleving. De redenering luidt dat kiezers stemmen op basis van eigenbelang en niet de nodige kennis en inzichten hebben in beleidsproblematiek, in tegenstelling tot vertegenwoordigers. "Your representative owes you, not his industry only, but his judgment; and he betrays, instead of serving you, if he sacrifices it to your opinion" (Burke, o.c. Elster, 1999, p. 3). Verkozenen hebben de plicht om met een gegeven stem hun zin te doen. Verkiezingen zijn dan een graadmeter voor de mate waarin verkozenen erin geslaagd zijn om een draagvlak te creëren voor genomen beslissingen.

Er bestaan niet veel dj's van wie de set is opgesteld aan de hand van verzoekjes uit het publiek. Een dj wordt ingehuurd op basis van zijn of haar muziekexpertise om de juiste plaatjes uit te kiezen. ${ }^{3}$ Net dat is de garantie voor een goed feestje.

Uiteraard is de opdeling in verschillende vormen van vertegenwoordiging in essentie een theoretische aangelegenheid (Devos, 2016). Bovendien spelen politieke partijen vandaag een cruciale rol in de vertegenwoordigingsrelatie (als kiezers stemmen op basis van partijprogramma's, worden de verkozenen van de respectievelijke partijen verondersteld die uit te voeren) (Heywood, 1997). Toch blijft de historische tweedeling tussen delegate en trustee tot op vandaag een zinvol perspectief om te kijken naar vertegenwoordiging in actuele politieke vraagstukken. De tweedeling is immers terug te brengen tot de vraag of politici verondersteld worden af te tasten waarvoor er een draagvlak is, dan wel de plicht hebben om een draagvlak te creëren. Vandaag blijft die historische vertegenwoordigingsvraag opmerkelijk relevant in het publieke debat rond democratie. 


\section{De euro die te belangrijk was om over te laten aan het volk}

Toen de eurocrisis een van zijn vele hoogtepunten bereikte en Gorgios Papandreou het Europees overeengekomen reddingsplan voor zijn land aan het Griekse volk wou voorleggen door middel van een referendum, werd de voormalige Griekse premier aan de schandpaal genageld. Het Europese reddingsplan dat technocraten en experts ontwikkeld hadden, was het enige alternatief om Griekenland - en aldus de andere landen van de eurozone erbovenop te helpen. Een voorstel om dat plan in de handen van het volk te leggen, werd beschimpt als 'onverantwoordelijk', 'populistisch' en 'zot'. Dat het vooral zot was dat de Griekse bevolking geen zeg had over een plan dat tot een sociaal bloedbad rond de Akropolis zou leiden, kreeg in het Justus Lipsiusgebouw weinig gehoor. Voornamelijk onder druk van Nicolas Sarkozy en Angela Merkel, werd Papandreou gedwongen zijn referendumvoorstel in te trekken. Vervolgens was hij veroordeeld zijn premierschap over te laten aan zijn opvolger, die op zijn beurt weer veroordeeld was tot het uitvoeren van het Europese reddingsplan. Nochtans was er voor dit 'enige mogelijke alternatief' geen draagvlak.

Om die reden wees Hendrik Vos (2011), politicoloog aan het Centrum voor EU Studies, erop dat de renteverschillen op lange termijn weleens minder belangrijk zouden kunnen zijn dan de spread die ontstaat tussen politici en de publieke opinie. Zijn collega's Ferdi
De Ville en Jan Orbie (2011) vroegen zich af in wiens belang die euro is, als die het koste wat het kost gered moet worden en dit te belangrijk is om over te laten aan het volk. Meer nog, als een Europees herstelplan voor een land niet in vraag mag worden gesteld, toont dat evenzeer aan hoe nationale parlementsverkiezingen er voor de galerij zijn. Socialisten, conservatieven en liberalen gaan allemaal met een verschillend programma naar de Griekse kiezer, op zoek naar zetels. De kiezer kiest op basis van wat de verschillende partijen aan hen voorleggen. Maar uiteindelijk worden de verkozenen veroordeeld tot het uitvoeren van wat de staats- en regeringsleiders van de meest zwaarwichtige lidstaten overeenkwamen. Wat op het spel staat, is immers van te groot belang om domweg in handen te leggen van de kiezer.

\section{Als het volk beslist, meer doden op de weg}

Hoe aannemelijk het bovenstaande voorbeeld het ook maakt dat in een democratie niets zo belangrijk kan zijn dat het volk er niét over mag beslissen, is een dergelijke invulling van politieke vertegenwoordiging vandaag ook niet onbetwist. Die kritiek beperkt zich trouwens niet tot de complexe, meerlagige context van de Europese besluitvorming (cf. 'waarom zou de Griekse bevolking het recht hebben om een Europees reddingsplan weg te stemmen dat de rest van de eurozone kan schaden?'), noch tot een crisissituatie (cf. 'in tijden van 
complexe crisissen rekenen we op onze leiders').

Neem bijvoorbeeld de recente berichtgeving over de uitbreiding van de $130 \mathrm{~km} / \mathrm{u}$-limiet op Nederlandse autosnelwegen. De VVD twitterde dat "veel mensen ontzettend blij zijn met de tijdswinst en het doorrijden”. Je zou kunnen stellen dat - vanuit het delegate-model een partij geënt op individuele vrijheid het aan haar kiespubliek verplicht is een dergelijke maatregel te verdedigen. De vraag is of de samenleving hiermee het best gebaat is.

Wat niet onder de hashtag van de VVD ‘\#vroemvroem' werd vermeld, was dat uit de publieke database waarin de Nederlandse politie verkeersongelukken met lichamelijke letsels registreert ('Bestand van geRegistreerde Ongevallen in Nederland'), blijkt dat in 2015 het percentage dodelijke slachtoffers veel groter was daar waar $130 \mathrm{~km} / \mathrm{u}$ gereden mocht worden, in vergelijking met de 120- en zeker de 100-trajecten (SWOV, 2015). Je kan je dus de vraag stellen of het niet de plicht is van de overheid om individuele vrijheid te begrenzen om de (veiligheid in de) samenleving te beschermen, en of dit al dan niet zo'n geval is. Als de kiezer echter sneller wil rijden, dan is het de plicht van de vertegenwoordiger als lasthebber om hier hoe dan ook gevolg aan te geven. Waar 'mensen blij mee zijn', daar moeten vertegenwoordigers naar handelen. Maar dat mensen die sneller willen rijden, niet alleen het veiligheidsrisico nemen voor zichzelf maar ook voor anderen, daar wordt aan voorbijgegaan (\#boemboem). Wat het nastreven van individueel eigenbelang betekent voor de samenleving, doet er niet toe. Het resultaat is de geaggregeerde uitkomst van waar individuen voor zichzelf de balans tussen vrijheid en veiligheid willen plaatsen, en niet waar we willen dat die balans ligt voor - en in - onze samenleving.

Als we het van het oordeel van de kiezer hadden laten afhangen, dan was de verplichting tot het dragen van een gordel - om in hetzelfde thema te blijven - er nooit gekomen. De maatregel was immers erg onpopulair; een draagvlak was er niet. In een democratie waar vertegenwoordigers lasthebbers zijn, is het invoeren van die maatregel ondenkbaar. Niettemin is de stelling dat een samenleving waarin automobilisten de vrijheid hebben om geen gordel te hoeven dragen een betere is, amper verdedigbaar. Een voorstel tot afschaffing van die maatregel zou om die reden vandaag juist op een gebrek aan draagvlak botsen.

\section{Elk nadeel hep zijn voordeel}

De bovenstaande praktijkvoorbeelden tonen aan dat de theoretische discussie of het de plicht is van vertegenwoordigers om af te tasten waarvoor er een draagvlak is, dan wel dat zij de plicht hebben om een draagvlak te creëren, doorleeft in het hedendaagse debat over democratie. In de praktijk stellen vertegenwoordigers zich dan ook, afhankelijk van het beleidsvraagstuk in kwestie, zowel als lasthebber en vertrouweling op (Pitkin, 1972). De 
voor- en nadelen van de ene dan wel de andere manier van vertegenwoordiging zijn immers niet absoluut. Een vertrouweling kan bekritiseerd worden voor zijn of haar elitaire opstelling door vanuit een ivoren toren aan het volk te verkondigen wat goed voor hen is, ook al weet het volk dat zelf nog niet. Een lasthebber kan bekritiseerd worden, omdat het zwalkend op zoek gaan naar draagvlak bezwaarlijk de samenleving als geheel ten goede komt. Het resultaat is een complexe praktijk van vertegenwoordiging die schippert tussen twee tegengestelde vormen van vertegenwoordiging.

In het licht van dit genuanceerde verhaal is de keuze van vertegenwoordigers voor meer burgerinspraak echter opmerkelijk eenduidig.

\section{Participatieve democratie in theorie: de vertegenwoordiger als lasthebber}

Als antwoord op de crisis van de representatieve democratie zetten volksvertegenwoordigers steeds meer en explicieter in op de participatieve democratie. Ze doen dat door burgers steeds vaker en op een meer directe wijze te betrekken bij de besluitvorming dan ze enkel een bolletje laten inkleuren op een stembiljet, eens om de zoveel jaren: participatie als institutionele aanvulling op de representatieve regeringsvorm.

Vanuit vertegenwoordigingsoogpunt kan de keuze van politici om in te zet- ten op meer burgerinspraak niet verantwoord worden vanuit het trustee-model van vertegenwoordiging. Een vertegenwoordiger als vertrouweling doet zijn of haar eigen zin. Het peilen naar specifieke verzuchtingen of eisen bij de burger is door een vertegenwoordiger als vertrouweling bijgevolg niet te rechtvaardigen: deze doen er immers niet toe.

Vanuit het delegate-model heeft de participatieve democratie wel de potentie om de relatie tussen vertegenwoordiger en vertegenwoordigde te versterken. Let wel, participatieve democratie is geen noodzakelijke voorwaarde vanuit die vertegenwoordigingsoptiek; burgerinspraak waarnaar de beleidsmaker als lasthebber geacht wordt te handelen, kan ook gewoon eng geïnterpreteerd worden als het uitoefenen van een stem tijdens verkiezingen. Maar de keuze voor meer burgerinspraak impliceert wel a priori een delegate-visie op vertegenwoordiging; pas als politici het ook belangrijk vinden dat er afgetast wordt voor welk beleid er een draagvlak is, kan de keuze voor een meer participatieve democratie in de invited space verantwoord worden.

Politicologen Andeweg (2003) en Deschouwer (2003) hebben het specifiek over 'responsiviteit' wanneer politici inspelen op wat onder de bevolking leeft tussen verkiezingen in en dit vertalen naar het politieke niveau. Ze categoriseren het als een specifieke invulling van de delegate-vertegenwoordiging: vertegenwoordiging van onderop (niet van bovenaf), maar dan niet enkel vooraf (klassieke delegatie van vertegenwoordigers naar vertegenwoordigden bij 
verkiezingen), maar ook achteraf (na de verkiezingen). Vooraf kan je immers niet weten met welke problemen een samenleving allemaal geconfronteerd zal worden tijdens een legislatuur, luidt de responsiviteitslogica, laat staan wat de bevolking daar vooraf over denkt.

De participatieve democratie maakt deel uit van een breder netwerk van diverse democratische besluitvormingsmechanismen en bijbehorende vertegenwoordigingspatronen. Samen vertellen ze een complex en genuanceerd verhaal. Dan is de absolute keuze voor deze of gene vorm van vertegenwoordiging uiteraard niet wenselijk. Maar wanneer de burger naar zijn of haar input gevraagd wordt tussen verkiezingen door, houdt dat onvermijdelijk in dat de vertegenwoordiger er in die context van uitgaat dat het zijn of haar plicht is om te beantwoorden aan de specifieke verzuchtingen of eisen van de burgers. Met andere woorden: dat een vertegenwoordiger er in die context niet van uitgaat dat het zijn of haar plicht is om naar eigen goeddunken te handelen en om vervolgens beleidsverantwoording te zoeken in de output. ${ }^{4}$

Hoe intuïtief en vanzelfsprekend de vertegenwoordigingsconsequenties van de participatieve democratie ook mogen zijn, in de praktijk lijken vertegenwoordigers hier flexibel en opportunistisch mee om te springen. Meer nog dan een weinig evidente vertegenwoordigersrelatie, ontstaat op die manier een vertegenwoordigingspraktijk die de democratie onbetwistbaar schade berokkent. Weinig vanzelfsprekend en contra-intuitief, maar vooral niet onschuldig.

\section{Participatieve democratie in de praktijk: de onbetrouwbare vertegenwoordiger?}

"Ik ben minister, geen tovenaar. Ik ben op zoek naar mensen met een visie, die in concrete werkgroepen mee het debat willen aangaan met experts en overheden” (Galant, 2015). Dat was de oproep die gewezen federaal minister voor Mobiliteit Jacqueline Galant via een open brief aan de Belgische burger richtte. Geen uit teflon en beton opgetrokken minister, maar iemand die - zoals eenieder van ons - onvolmaakt en hulpbehoevend is (Renson, 2015). Een menselijke leider die de bijstand vraagt van haar burgers om de levensverwoestende drama's op de weg te verhoeden, omdat ze het zelf ook niet allemaal weet. Het getuigt van bewonderenswaardige politieke moed.

Galant gaf aan te geloven in het potentieel van de burger om in debat met politici en experts het beleid te verrijken en een minister te helpen. Uiteindelijk kreeg de burgerinspraak vorm door middel van een online enquête, poll en enkele debatten met experts (Fluit, 2015). De bedenkelijkheid van een praktijk waarin de inspraak van burgers beperkt werd tot het online al dan niet valideren van uitgelijnde voorstellen van een minister en tot het mogen geven van een mening over de thema's en voorstellen die vooraf uitgetekend en afgelijnd waren door cabinettards, kreeg in het publieke debat veel aandacht (Peeters, 2015; Renson, 2015). Vlaams mobiliteitsexpert Kris 
Peeters verweet de minister om via een weloverwogen, suggestieve werkwijze burgerinspraak te misbruiken in een zoektocht naar legitimiteit voor wat ze vooraf al wist te willen uitvoeren. Die kritiek van binnenuit toont zeker niet aan dat de minister ondubbelzinnig getracht heeft haar intenties te realiseren.

Onderzoek naar participatie in de invited space lijkt dan ook een verschil vast te stellen tussen het discours en de praktijk van burgerinspraak. In de praktijk zijn beleidsmakers in Europa, Vlaanderen en Nederland terughoudender om de burger ook daadwerkelijk inspraak te verlenen (Graaf, Schaap, \& Theuns, 2016; Koster et al., 2011; Dezeure \& De Rynck, 2011; Peppel, 2001).

Op die manier gaan vertegenwoordigers eraan voorbij, dat het niet onschuldig is om de burger te vragen om te participeren. Het vraagt een vrijwillige opoffering van energie, enthousiasme, engagement en (vrije) tijd. Inspraak die niet uitmondt in invloed en gewoon gehouden wordt voor de galerij - omdat burgerinspraak nu eenmaal in de mode is en het onpopulair is om er niet op in te zetten - geeft de burger een klap in het gezicht. Hij of zij die een vrije avond of zondag opofferde, wordt geridiculiseerd. Je kan ervoor kiezen als beleidsmaker om niet in te zetten op een participatieve democratie (als vertrouweling én als lasthebber), maar pretenderen belang te hechten aan inspraak (wat participatie in de invited space per definitie veronderstelt, cf. supra) en die vervolgens niet serieus nemen, dat gaat te ver.
Participatieve democratie dreigt een instrument te zijn waarvan men hoopt dat wanneer men het discours hanteert dat men wil kijken naar wat er leeft onder de bevolking, men - onder het mom van democratische vernieuwing - voldoende draagvlak gecreëerd heeft om uiteindelijk naar eigen goeddunken te kunnen handelen. Dit is geen vertegenwoordiging als lasthebber, noch als vertrouweling. Dit is onbetrouwbare vertegenwoordiging. Het legt de vinger op de wonde van de crisis van de representatieve democratie, een crisis waarin volksvertegenwoordigers amper vertrouwen genieten van diegenen die ze vertegenwoordigen.

\section{Participatieve democratie vergt een vertegenwoordiger als lasthebber \\ Minder paaien, meer verantwoordelijkheid dragen}

Als een vertegenwoordiger van mening is dat het in een bepaalde context is aangewezen om finaal geen rekening te houden met specifieke verzuchtingen of eisen van de vertegenwoordigden, maar burgers toch vraagt om input, dan moet die hier ook eerlijk over durven te zijn: "Ik ben op zoek naar mensen met een visie, die mee het beleid vorm willen geven. In ruil voor hun tijd en engagement mogen ze hun mening geven. Uiteindelijk ben ik als beleidsmaker echter niet gebonden om dit te vertalen in invloed, laat staan in macht. Het is 
immers mijn plicht als volksvertegenwoordiger om naar eigen inzichten te handelen."

Dat een praktijk waarbij vertegenwoordigers zich aanbieden als lasthebber maar handelen als vertrouweling, resulteert in een burger die het gevoel heeft niet serieus genomen te worden, kan moeilijk verrassen.

Dat de participatieve democratie een vertegenwoordiger vergt die zijn of haar verantwoordelijkheid draagt en de gevraagde burgerinspraak serieus neemt, impliceert niet alleen het daadwerkelijk verlenen van invloed en macht aan de burger, maar betekent ook dat de burger daadwerkelijk als burger benaderd wordt in het proces van inspraak. Door zijn of haar inbreng in de participatieve democratie niet te verengen tot de keuze van een woord van twee of drie letters. Door in te zetten op creatievere vormen van participatie waarin burgers niet benaderd worden als consumenten die moeten oordelen over wat hun aangeboden wordt, maar als burgers die zelf in staat zijn om (in overleg met anderen) tot creatieve oplossingen te komen.

In de nasleep van het Oekraïnereferendum plaatste David Van Reybrouck (2016), oprichter van de G1000 en de grootste bezieler van de deliberatieve democratie in de Lage Landen, vraagtekens bij de keuze van de initiatiefnemers voor een referendum zonder meer. Je legt aan de inwoners van eenzelfde appartementsblok de keuze tussen een houten of een zinken dakgoot, zonder dat je offertes laat opmaken, de syndicus $^{5}$ inschakelt en de eigenaars samen- brengt. Dat gebrek aan informatie, expertise, tijd en overleg is verbijsterend, volgens Van Reybrouck.

Daar valt zeker iets voor te zeggen. Maar de wijze waarop Van Reybrouck de pijnpunten van dit referendum als vorm van participatieve democratie blootlegde, toont aan dat die veel dieper liggen dan op het eerste gezicht lijkt.

Stel dat de syndicus verschillende offertes had opgevraagd, dat hij alle inwoners uitnodigde voor een overleg waar experts van houten en zinken dakgoten aanwezig waren, waar de inwoners vragen konden stellen en met elkaar in debat konden gaan, en waar de syndicus besloot om die kwestie op de twee volgende bijeenkomsten ook op de agenda te plaatsen. Wat dan? Dan zou al snel blijken dat de inwoners die met het idee afkwamen om de dakgoot te vervangen, eigenlijk geen uitgesproken voorstander zijn van een houten dan wel zinken dakgoot, en dat er eigenlijk zelfs niets mis is met de huidige dakgoot. Al snel zou blijken dat het hun eigenlijk gaat over de manier waarop er samengeleefd wordt in het gebouw. Over nachtlawaai en vandalisme. Over spelende kinderen en blokkende studenten. Over het niet buiten zetten van elkaars vuilnisbakken en het gebrek aan contact onder de buren. Dan zouden inzichten van experts over het belang van een goede lasverbinding in de dakgoot weinig verhelderend zijn en zouden de opgevraagde offertes de prullenmand in gaan. Tot een stemming over een houten of zinken dakgoot zou het nooit komen. Met de huidige dakgoot is immers niets mis. 


\section{Meer timmeren, minder zagen}

Burgerparticipatie verdient een betere voorstelling dan de wijze waarop ze invulling krijgt in een referendum. De onvrede van de initiatiefnemers van het Oekraïnereferendum over het gebrek aan invloed van de burger op de Europese besluitvorming mag dan zeer legitiem zijn, de manier waarop hieraan uiting gegeven werd, is een blamage voor de democratie. Het is een medicijn voorgeschreven door een kwakzalver, dat de symptomen verergert waartegen het zou moeten strijden.

Er zijn buren die hun dakgoot herstellen. Er zijn buren die regenwater recupereren en met elkaar delen. En er zijn buren die de syndicus en medebewoners aan tafel roepen om problemen te bespreken over de manier waarop samengeleefd wordt in hun pand. Dat zijn burgers die timmeren. In een referendum wordt de inbreng van de burger gemakshalve beperkt tot (dakgoten) zagen. Maar hoe moet er getimmerd worden aan het Europese huis van de toekomst? Wie krijgt er welke kamer? Op welke manier moet er onder die dakgoot samengeleefd worden? Welke taken nemen de bewoners op zich en waar komt de syndicus tussen? Het antwoord is niet ja of neen.

Burgerinspraak serieus nemen, impliceert de burger de mogelijkheid geven zijn of haar potentie te ontwikkelen om zelf op een creatieve wijze bij te dragen aan de politieke besluitvorming. Want als je niet van mening bent dat hij of zij hiertoe in staat is, waarom zou je dan überhaupt (op enige wijze) naar zijn of haar inbreng vragen? Bovendien houdt het benaderen van burgers als burgers in de publieke ruimte (wat de participatieve democratie vergt) ook opportuniteiten in voor vertegenwoordigers.

\section{Participatieve democratie verstrekt een vertegenwoordiger als vertrouweling}

Volgens recente inschattingen zou de gemiddelde Belgische en Nederlandse burger 250 à 350 keer per dag geconfronteerd worden met reclame. Honderden keren per dag worden we eraan herinnerd dat we consumenten zijn (Faasse, 2012; The House of Brands, 2012). Tel hierbij de nog veelvuldiger confrontaties met verpakking en labels van merken bij, en het is niet verwonderlijk dat we in situaties waar de wetten van de markt niet spelen, redeneren volgens een consumentenlogica (Renson, 2016). Daarenboven versterken ook publieke actoren dat. Door State of the Unions, regeringsverklaringen en bestuursakkoorden waarin burgers als 'klanten' worden aangesproken. Door verkiezingen en referenda, waarbij kiezers eens om de zoveel tijd gevraagd wordt om te oordelen over wat anderen aan hen aanbieden, met een potlood in de hand achter een gordijn. Het resultaat is dat het woord 'burger' vandaag enkel nog doet denken aan 'double cheese' en 'eurodeals'. 
Dat een huidig Vlaams burgemeester dan verkondigt dat 'hij weet hoe hij de klimaatopwarming moet oplossen, maar het niet doet omdat hij anders niet meer verkozen geraakt', is begrijpelijk (afgezien van hoe problematisch de absolute priorisering van het opnieuw verkozen geraken is). Een politiek project gaat over burgers die nadenken over hoe de samenleving, waarin ze op elkaar zijn aangewezen om samen te leven, vorm moet krijgen (Renson, 2016). Een politiek project waarin burgers als consumenten benaderd worden en zich zodanig gaan gedragen, is een samenleving van individuen die - net zoals in een marktsituatie, op zoek gaan naar de beste eurodeal voor zichzelf. Dit is een democratie die er niet voor zal kiezen om de klimaatopwarming op te lossen: wij, de huidige generatie westerlingen, die er het meest verantwoordelijk voor zijn, worden door de gevolgen ervan het minst getroffen. Dit is een democratie waarin oorlogsvluchtelingen van wie de kennis of vaardigheden niet overeenstemmen met de knelpunten van die arbeidsmarkt waar hun oorlogsvlucht hen brengt, geen kans maken op integratie: zij kosten de samenleving meer dan ze opleveren. Dit is een democratie waarin solidariteit in het beste geval een jammerlijke noodzaak is: we hebben Griekenland schoorvoetend en met tegenzin tijdens de eurocrisis gered, omdat anders onze banken hier overkop zouden gaan. Maar een democratie van consumenten is een samenleving waarvoor geen burger zou kiezen.
Als beleidsmakers burgers als burgers benaderen en zodoende de kans geven zich als burger heruit te vinden in de publieke ruimte, biedt dit ook perspectieven voor beleidsmakers om als vertrouwelingen in die andere, klassieke representatief democratische beleidscontext daadwerkelijk te durven kiezen voor wat zij denken waar de samenleving als geheel bij gebaat is. Iets waarvoor zij door (zagende) consumenten steeds electoraal afgestraft zouden worden, zoals die Vlaamse burgemeester juist inschat, maar waarvoor (timmerende) burgers de ruimte geven aan hen. Daar waar het vandaag van lovenswaardige moed betuigt, heeft de participatieve democratie met andere woorden de potentie om van het trustee-model opnieuw een geloofwaardig alternatief te maken voor politici die bovenal opnieuw verkozen willen worden.

De participatieve democratie wil burgers opnieuw meer betrekken bij de politieke besluitvorming. Er valt iets voor te zeggen om dat niet te doen, maar er valt niets voor te zeggen om burgers te paaien en te betrekken voor de galerij. Wie inzet op participatieve democratie, pretendeert per definitie belang te hechten aan burgerinspraak. Dat niet doen is contra-intuïtief en weinig vanzelfsprekend. Maar vooral ook niet onschuldig. Come senators, congressmen. Please heed the call. Don't stand in the doorway. Don't block up the hall. For the times they are a-changing. ${ }^{6}$ 


\section{Noten}

1. Wanneer de burger participeert op vraag van de overheid, in een ruimte die geconstrueerd en gefaciliteerd wordt door die laatste.

2. Zowel Reynaert als Dijkstal had (ook) kritiek op die benadering. Dijkstal hield een pleidooi voor verantwoordelijke burgers, waarin politiek meer is dan het uitvoeren van de wensen van burgers. Reynaert vindt dat dj's niet enkel input moeten vragen aan het publiek, maar zelf ook een visie moeten uitdragen over wat zij goede muziek vinden (cf. infra).

3. Cf. Reynaert et al. (2006).

4. Cf. input vs. outputlegitimiteit (Scharpf, 1999).

5. Voorzitter van de Vereniging van Eigenaren.

6. Bob Dylan, The times they are a-changin'.

\section{Bibliografie}

Andeweg, R. (2003). Beyond representativeness? Trends in political representation. European Review, 11(2), 147-161.

Deschouwer, K. (2003). De vertegenwoordigende democratie. In T. Heysse \& W. Goossens (Eds.), Democratie als filosofisch vraagstuk (pp. 33-49). Kapellen: Uitgeverij Pelckmans.

Devos, C. (2016). Democratie en vertegenwoordiging. In C. Devos (Ed.), Een plattegrond van de macht. Gent: Academia Press.

Dezeure, K., \& Rynck, F. de (2011). Participatie wordt ge(s)maakt! Over de visie van politici en ambtenaren op participatie. Brussel: Steunpunt Beleidsrelevant Onderzoek 2007-2011. Bestuurlijke Organisatie Vlaanderen.

Dijkstal, H. (2001, 23 januari). Democratie kan geen jukebox zijn met ieders favoriete liedje. De Volkskrant.

Elster, J. (1999). Deliberative democracy. Cambridge: Cambridge University Press.

Faasse, J. (2012). Hoeveel reclame ziet u per dag? Geraadpleegd via http://uitbijter.nl/nl/2012/03/hoeveel-reclameziet-u-per-dag/

Fluit, A. (2015, 15 december). Galants burgerbevraging biedt maar weinig ruimte voor inspraak. De Morgen.

Foa, R. S., \& Mounk, Y. (2016). The danger of deconsolidation. Journal of Democracy, 27(3), 5-17.

Galant, J. (2015, 20 oktober). Weggebruikers, nu is het aan u. De Standaard.

Graaf, L. de, Schaap, L., \& Theuns, M. (2016). Raadswerk is maatwerk. Hoe kan je als raad(slid) meer kleur geven aan de lokale democratie? Tilburg: Tilburgse School voor Politiek en Bestuur.

Heywood, A. (1997). Politics. Houndsmill: Macmillan.

Koster, K. de, Kampen, J., Caluwaerts, D., Cloedt, A. S. de, Depauw, S., \& Deschouwer, K. (2011). Democratie en de kloof tussen discours en praktijk. Burgerparticipatie, overheidsbeleid en tevredenheid op het lokale niveau. Gent: Academia Press.

Peeters, K. (2015, 8 december). Waarom een helm dragen gevaarlijk is. De Standaard.

Peppel, R. van de (2001). Effecten van interactieve besluitvorming. In J. Ede- 
lenbos \& R. Monnikhof (Eds.), Lokale interactieve beleidsvorming (pp. 3349). Utrecht: Lemma BV.

Pitkin, H. F. (1972). The concept of representation. Berkeley: University of California Press.

Renson, T. (2015, 22 december). Inspraak voor de galerij. De Standaard.

Renson, T. (2016, 21 november). Consument maakt democratie kapot. De Standaard.

Reynaert, H., Walle, S. van de, \& Verlet, D. (2006). Naar een DJ-overheid? Brugge: Vanden Broele.

Scharpf, E. (1999). Governing in Europe: Effective or democratic? Oxford: Oxford University Press.

Stichting Wetenschappelijk Onderzoek Verkeersveiligheid (SWOV) (2015). Be- stand van geRegistreerde Ongevallen in Nederland.

The House of Brands (HOB) (2012). De mythe van 3000 reclames per dag. Geraadpleegd via http://www.thehouseofbrands.be/blog-archief/de-mythevan-3000-reclames.html

Van Reybrouck, D. (2016, 7 april). Hoe is het mogelijk dat we cruciale kwestie beslechten met een blind instrument als het referendum. De Morgen.

Ville, F. de, \& Orbie, J. (2011, 3 november). Zwijgen in het belang van de euro? De Standaard.

Vos, H. (2011, 17 november). Eurocrisis zet democratie op stand-by. De Standaard.

World Values Survey (WVS) (2016). Wave 6: 2010-2014 Official Aggregate. Madrid: World Values Survey Association. 